\title{
Penggunaan Asthma Control Test (ACT) secara Mandiri oleh Pasien untuk Mendeteksi Perubahan Tingkat Kontrol Asmanya
}

\author{
Yessy Susanty Sabri, Yusrizal Chan
}

\begin{abstract}
Abstrak
Asma adalah penyakit dengan spekrum gejala yang luas dan gejala yang sering dilaporkan pasien kepada dokter sangat beragam, tergantung dari persepsi masing-masing pasien. Pendekatan terbaru dalam penatalaksanaan pasien asma yaitu pasien dapat hidup bebas tanpa terganggu oleh gejala penyakitnya. Tujuan dari penelitian ini adalah untuk mengetahui efektifitas penggunaan ACT secara mandiri oleh pasien asma untuk mendeteksi perubahan tingkat kontrol asmanya. Metode yang digunakan adalah Studi Analisis kohort Prospektif. Didapatkan 32 orang pasien asma yang berobat ke poliklinik Paru RS M. Djamil Padang, yang bersedia ikut dalam penelitian ini. Efektifitas penggunaan ACT secara mandiri oleh pasien sebagai alat untuk mendeteksi perubahan tingkat kontrol asma, cukup efektif karena penilaian tingkat kontrol asma pasien sama dengan dokter yaitu 78,1\%. Efektifitas ACT tidak berhubungan dengan tingkat pendidikan pasien, derajat keparahan asma, tingkat pengetahuan awal pasien terhadap penyakit asma serta lama menderita asma. Selama penelitian tidak ditemukan kejadian eksaserbasi pada pasien penelitian.
\end{abstract}

Kata kunci: Asma, asma kontrol tes

\begin{abstract}
Asthma is a disease with wide spectrum symptoms and the patient's symptoms are often reported to doctors also with wide range of diversity, depending on the perception of each patient. New approaches in the management of asthma patients i.e. patients can live freely without being distracted by the symptoms of the disease. The purpose of this study was to determine the effectiveness of the use of ACT independently by asthma patients to detect changes in the level of asthma control. The method used was a prospective cohort study analysis. There were 32 asthma patients who went to the Lung polyclinic of M. Djamil Hospital Padang and were willing to participate in the study. Effective use of ACT independently by the patient as a tool to detect changes in the level of asthma control is quite effective in which the assessment level of asthma control between patient and the doctor is equal with the value $78.1 \%$. The effectiveness of ACT is not related to the educational level of the patient, severity of asthma, the level of prior knowledge of the patients and the period of suffering asthma. During the study found no incidence of exacerbations in the patients. English, Arial 9 italic
\end{abstract}

Keywords: asthma, asthma control test

Affiliasi penulis : Bagian Pulmonolgi Fakultas Kedokteran Universitas Andalas

Korespondensi : Yessy Susanty Sabri, email: yessysabri@fk.unand.ac.id, Telp: 0751-27253

\section{PENDAHULUAN}

Asma merupakan suatu penyakit obstruksi saluran nafas yang dapat mengenai mereka yang memiliki faktor resiko. Penyakit ini mempunyai spektrum gejala klinis yang bervariasi mulai dari ringan hanya berupa batuk, sampai berat berupa serangan yang mengancam jiwa. Keluhan yang sering dilaporkan pasien kepada dokter beragam, tergantung 
persepsi masing-masing pasien. ${ }^{1}$

Pendekatan terbaru dalam penatalaksanaan pasien asma adalah menjaga agar pasien tetap berada dalam keadaan asma yang terkontrol total, yaitu pasien dapat hidup bebas tanpa terganggu oleh penyakitnya. Definisi asma terkontrol total adalah tidak ada atau minimal gejala harian asma, tidak ada keterbatasan fisik termasuk aktifitas, tidak ada gejala malam atau terbangun malam hari oleh karena asma, tidak ada atau minimal pemakaian obat pelega, hasil tes fungsi paru normal atau mendekati normal serta tidak ada eksaserbasi. ${ }^{2}$

Adanya pemahaman yang beragam tentang gejala asma menyebabkan sulitnya pengontrolan terhadap perburukan yang mulai terjadi pada pasien. Pasien yang biasa mengalami serangan sesak nafas berat mungkin tidak memperhatikan timbulnya batukbatuk terutama pada malam atau dini hari yang mengganggu tidur mereka. Padahal keadaan ini sebenarnya sudah menunjukkan bahwa asma yang mereka derita sudah tidak terkontrol lagi. Bila hal ini tidak cepat ditanggulangi dengan penatalaksanaan yang sesuai, maka akan dapat menyebabkan terjadinya serangan eksaserbasi asma yang akan meningkatkan morbiditas serta mortalitas pasien. ${ }^{3}$

Pengenalan dini terhadap perubahan tingkat kontrol asma pasien yang dapat dideteksi sendiri oleh pasien merupakan tindakan yang sangat penting, karena dapat mencegah terjadinya serangan akut asma berat. Pasien dapat segera mengenali tandatanda perburukan penyakit mereka, sehingga intervensi yang sesuai dengan keadaan pasien dapat segera dilakukan. ${ }^{2}$

Salah satu alat yang dapat dipakai oleh pasien dalam mendeteksi tingkat kontrol asmanya adalah dengan menggunakan kuesioner Asthma Control Test (ACT) yang terdiri dari lima pertanyaan yang dapat mendeteksi adanya perburukan penyakit hal tersebut berdasarkan gejala harian, gejala malam, hambatan aktifitas, penggunaan obat pelega serta penilaian sendiri pasien terhadap penyakitnya. ${ }^{4}$

Disebabkan hal diatas maka sangat penting bagi pasien asma untuk segera mengenal tanda-tanda perburukan penyakit karena penanganan dini yang tepat akan mencegah terjadinya serangan eksaserbasi akut asma yang berat. Penanganan dini terhadap asma yang tidak terkontrol dapat menurunkan angka morbiditas dan mortalitas penyakit. Penelitian untuk pengetahui seberapa efektifkah ACT mendeteksi perubahan tingkat kontrol asma bila digunakan secara mandiri oleh pasien serta faktor apa saja yang akan mempengaruhi ketepatan tersebut sangat diperlukan agar dapat membantu pasien dan dokter menjaga asma dalam keadaan terkontrol total.

\section{Perumusan masalah}

Kemampuan mendeteksi tingkat kontrol secara mandiri oleh pasien dapat membantu dalam deteksi dini perubahan tingkat kontrol asma sehingga intervensi yang diperlukan cepat dilakukan. Salah satu alat yang dapat dipakai pasien dalam menentukan perubahan tingkat kontrol asma secara mandiri adalah dengan menggunakan kuesioner ACT. Seberapa efektifkah penggunaan ACT secara mandiri oleh pasien dalam mendeteksi perubahan tingkat kontrol asmanya.

\section{Tujuan penelitian}

a. Tujuan Umum Mengetahui efektifitas penggunaan ACT secara mandiri oleh pasien asma untuk mendeteksi perubahan tingkat kontrol asmanya.

b. Tujuan khusus

1. Membandingkan perbedaan dalam mendeteksi perubahan tingkat kontrol oleh pasien dengan yang didapatkan oleh dokter.

2. Mengetahui faktor-faktor yang berhubungan dengan efektifitas pasien dalam mendeteksi perubahan tingkat kontrol asma menggunakan ACT.

3. Mengetahui angka kejadian eksaserbasi pada pasien yang melakukan kontrol asmanya secara mandiri dengan ACT selama penelitian.

\section{Manfaat Penelitian}

1. ACT dapat digunakan sebagai alat bantu yang lebih sederhana untuk mengetahui tingkat kontrol asma penderita secara mandiri. 
2. Mengetahui faktor yang akan mempengaruhi penilaian pasien terhadap tingkat kontrol asmanya.

3. Sebagai dasar bagi penelitian selanjutnya.

\section{TINJAUAN PUSTAKA}

1. Prinsip penatalaksanaan asma secara kontrol asma

Asma adalah gangguan inflamasi kronis saluran nafas yang melibatkan banyak sel dan elemennya. Inflamasi kronik menyebabkan peningkatan hiperresponsif jalan nafas yang menimbulkan gejala episodik berupa mengi, sesak nafas, dada terasa berat dan batuk-batuk terutama malam atau dini hari. Episodik tersebut berhubungan dengan obstruksi jalan nafas yang luas bervariasi dan seringkali bersifat reversible dengan atau tanpa pengobatan. ${ }^{1}$

Indonesia termasuk Negara dengan angka prevalensi asma yang rendah yaitu sekitar 3,5\%, tapi karena jumlah penduduk yang besar maka diperkirakan sekitar 5 juta jiwa penduduk Indonesia adalah penderita asma. Kenyataan diatas menyebabkan asma memberikan dampak yang cukup besar karena tingginya beban biaya kesehatan, angka kematian dan kesakitan penderita asma. Sehingga penanggulangan dini terhadap semua gejala asma yang akan mengganggu aktifitas sehari-hari pasien asma menjadi target utama dalam penatalaksanaan pasien asma. $^{5}$

Tahun 2006 melalui Global Inisiative for Asthma (GINA) dikeluarkanlah suatu bentuk tuntunan baru. Tuntunan ini menitik-beratkan kepada pengendalian terhadap gejala asma dengan menggunakan pengobatan tepat, serta mengupayakan pendeteksian dini terhadap perburukan gejala asma sehingga serangan eksaserbasi akut asma dapat dihindari. Pencegahan terhadap eksaserbasi asma memberikan banyak keuntungan yaitu mencegah progresifitas penyakit, menekan angka rawatan rumah sakit serta menurunkan angka moralitas asma. ${ }^{6}$ Berdasarkan GINA, asma yang terkontrol didefinisikan sebagai berikut:

1. Gejala asma yang minimal (sebaiknya tidak ada) termasuk gejala malam.
2. Tidak ada keterbatasan aktifitas termasuk latihan.

3. Kebutuhan bronkodilator (Agonis beta-2 kerja singkat) minimal atau tidak ada.

4. Variasi APE kurang dari $20 \%$.

5. Nilai APE normal atau mendekati normal.

6. Efek samping obat minimal (tidak ada).

7. Tidak ada kunjungan ke unit gawat darurat. Dalam prakteknya pasien asma dibagi menjadi 3 kelompok pasien berdasarkan tingkat kontrol asmanya, hal ini dapat dilihat pada tabel dibawah ini :

Tabel 1. Tingkatan kontrol asma pasien ${ }^{6}$

\begin{tabular}{|c|c|c|c|}
\hline \multicolumn{4}{|c|}{ TINGKAT KONTROL ASMA } \\
\hline \multirow{3}{*}{ Karakteristik } & Terkontrol total & $\begin{array}{l}\text { Terkontrol } \\
\text { sebagian }\end{array}$ & $\begin{array}{c}\text { Tidak } \\
\text { terkontrol }\end{array}$ \\
\hline & & salah satu poin & 3 / lebih poin \\
\hline & Semua poin & $(+)$ & $(+)$ \\
\hline Gejala harian & Tidak ada / $\leq 2$ kali $/ \mathrm{mg}$ & Lebih 2 kali / mg & Tiga poin \\
\hline \multicolumn{4}{|l|}{ Keterbatasan } \\
\hline aktifitas & Tidak ada & ada & atau lebih \\
\hline Gejala malam & Tidak ada & ada & positif \\
\hline \multicolumn{4}{|l|}{ Kebutuhan } \\
\hline pelega & Tidak ada / $\leq 2$ kali $/ \mathrm{mg}$ & Lebih 2 kali / mg & \\
\hline Fungsi paru & Normal & $<80 \%$ prediksi & \\
\hline
\end{tabular}

Fokus utama dokter berdasarkan tuntunan terbaru ini adalah mencapai serta mempertahankan keadaan asma yang terkontrol total pada pasien asma. Kerjasama yang baik antara dokter dan pasien dalam mencapai asma yang terkontrol total ini sangat penting oleh karena intervensi yang tetap dan cepat harus segera dapat dilaksanakan bila terlihat kecenderungan perubahan tingkat kontrol kearah perburukan. Berdasarkan penelitian Rabe dkk dengan kerjasama yang baik ini $80 \%$ pasien dapat mencapai tingkat asma yang terkontrol total. ${ }^{3}$

2. Pentingnya pasien mengetahui perubahan tingkat kontrol asma secara mandiri

Penderita asma sebagai orang yang berpotensi untuk mengalami serangan asma haruslah mempunyai pengetahuan yang baik tentang penyakit mereka secara baik, sehingga mereka dapat mengenali tanda-tanda yang menunjukkan terjadinya perburukan penyakit yang sebenarnya dapat dicegah

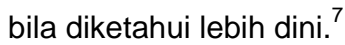

Oleh karena itu pemahanan terhadap tingkat kontrol asma serta kemampuan penderita asma dalam 
mendeteksi tingkat kontrol asma mereka setiap saat menjadi permasalahan utama dalam mencapai tingkat asma yang terkontrol total. Apabila pasien mengetahui dengan jelas apa yang akan menjadi pencetus penyakitnya, maka penderita dapat menghindari pencetus tersebut dan kemungkinan serangan asma dapat dihindari. Apabila pencetus tidak dapat mereka hindari maka mereka tahu apa langkah pencegahan yang akan diambil. ${ }^{6}$

Pada tuntunan GINA terbaru disediakan beberapa alat / kuesioner yang dapat dipakai secara mandiri oleh pasien dalam mengetahui tingkat kontrol asma mereka. Alat ini sangat mudah pemakaiannya. Dengan pelatihan yang baik maka diharapkan penggunaan kuesioner ini dapat membantu pasien mencapai serta mempertahankan tingkat asma yang terkontrol total. Beberapa kuesioner yang direkomendasikan oleh GINA adalah: ${ }^{6}$

1. Asthma Control Test (ACT)

2. Asthma Control Questionnaire (ACQ)

3. Asthma Therapy Assessment Questionnaire (ATAQ)

Komponen-komponen yang dinilai pada setiap kuesioner dapat dilihat pada tabel dibawah ini.

Tabel.2. Perbandingan komponen yang dinilai pada ACT, ACQ dan ATAQ. ${ }^{6}$

Tabel 2. Perbedaan komponen ACT, ACQ dan $A T A Q^{8}$

\begin{tabular}{lccc}
\hline & ACT & ACQ & ATAQ \\
\hline Gejala harian & V & V & \\
Gejala malam & V & V & V \\
Keterbatasan aktifitas & V & V & V \\
Penggunaan pelega & v & V & V \\
Fungsi Paru & & V & \\
Persepsi pasien terhadap kontrol & v & & V \\
Keparahan gejala & & V & \\
\hline
\end{tabular}

3. ACT sebagai alat pendeteksi yang dapat dipakai untuk mendeteksi tingkat kontrol asma secara mandiri.

Asthma Control Test merupakan alat yang dapat digunakan untuk mengevaluasi kontrol asma pada pasien dan dianjurkan pemakaiannya. Alat ini sangat sederhana dan mudah karena berisi 5 buah pertanyaan yang harus diisi oleh penderita, kemudian diberikan skor pada tiap jawaban pertanyaan dengan nilai skor 1 sampai dengan 5 . Nilai maksimal adalah 25 dengan pembagian sebagai berikut: ${ }^{9}$

- 19 atau kurang = asma tidak terkontrol

- 20-24 = asma terkontrol sebagian

- $25=$ asma terkontrol total

Keuntungan lain dari penggunaan ACT ini adalah dapat meningkatkan kualitas komunikasi antara dokter dan pasien karena pertanyaan pada ACT jelas dan konsisten, sehingga pasien lebih terbuka dan dapat menjawab pertanyaan dengan jujur. Validitas dari ACT dapat ditingkatkan dengan menggunakan spirometri serta penilaian ahli. Tingkat sensitifitas ACT adalah 68,4\% dan spesifisitas $76,2 \%$. Daftar pertanyaan pada ACT dapat dilihat pada tabel 3 dibawah ini. ${ }^{10}$

\section{KERANGKA KONSEPTUAL PENELITIAN} DAN HYPOTESIS PENELITIAN

DENGAN ACT PASIEN DAPAT MENINGKATKAN KEMAMPUAN SECARA MANDIRI DALAM MENDETEKSI PERBURUKAN TINGKAT KONTROL ASMANYA

PERUBAHAN TERAPI YANG DIBUTUHKAN PASIEN DAPAT DENGAN CEPAT DILAKUKAN

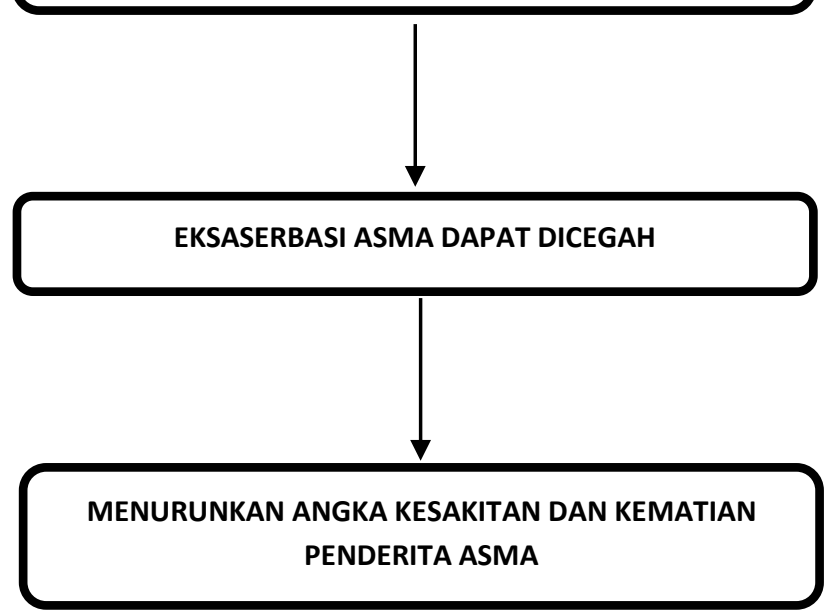

Gambar.1. Kerangka konsep penelitian

1. Hipotesis

ACT dapat secara efektif mendeteksi perburukan tingkat kontrol asma pasien. 


\section{METODE PENELITIAN}

1. Jenis Penelitian

Jenis penelitian ini adalah suatu Studi Analisis kohort Prospektif.

\section{Tempat dan waktu penelitian}

Penelitian ini dilakukan di Poliklinik Paru RS.

Dr. M. Djamil Padang dari bulan Juli September 2011.

\section{Subjek Penelitian}

Semua penderita asma yang berobat ke poli paru RS Dr. M. Djamil Padang mulai Juli September 2011 yang memenuhi Kriteria inklusi, dan bersedia menandatangani surat pernyataan bersedia ikut dalam penelitian. Kriteria inklusi:

- Semua penderita Asma yang telah didiagnosis sebagai asma yang berobat ke Poliklinik paru RS Dr. M. Djamil Padang.

- Bersedia menandatangani persetujuan untuk ikut dalam penelitian ini.

Kriteria ekslusi:

- Tidak bisa dilakukan spirometri

- Data tidak lengkap

\section{Variabel penelitian dan definisi operasional}

Variabel penelitian.

Variabel independen

Umur, Pekerjaan, jenis kelamin

Variabel dependen

: Pendidikan, lama

menderita asma, tingkat keparahan asma, tingkat pengetahuan pasien terhadap penyakit asma.

\section{Definisi Operasional}

1. Penderita asma : Pasien yang mempunyai riwayat asma atau gejala klinis yang sesuai penderita asma serta dibuktikan pada pemeriksaan spirometri dengan menggunakan bronkodilator, terjadi peningkatan reversibilitas sebesar $\geq 12 \%$ dan lebih $200 \mathrm{ml}$ dari hasil test prebronkodilator.

2. Asthma Control test (ACT) : suatu kuesioner yang berisi 5 pertanyaan untuk mengetahui tingkat kontro dari penderita asma yaitu terbagi atas tiga kategori berdasarkan total nilai yang didapat dari 5 pertanyaan:

- 19 atau kurang = Asma tidak terkontrol

- 20-24 = asma terkontrol sebagian

- 25 = asma terkontrol total

3. faktor-faktor internal yang mempengaruhi penilaian pasien dalam menilai tingkat kontrol asmanya adalah suatu faktor yang ada pada pasien dan memberikan pengaruh terhadap penilaian kontrol asma yang dilakukan secara mandiri oleh pasien hal tersebut meliputi :

- Pendidikan : dibagi atas

- Tingi : Minimal tamat Diploma 1 keatas

- Sedang : Tamat SMA

- Rendah : Tidak bersekolah sampai Maksimal Tamat SMP

- $\quad$ Tingkat keparahan asma pasien yang terdiri atas :

- Intermiten,

- Persisten ringan,

- Persisten sedang

- Persisten berat

Ditentukan dengan menggunakan kuesioner dan hasil spirometri.

- Tingkat pengetahuan pasien terhadap penyakit asma, dibagi atas :

- Tinggi : Mengetahui penyakit asma sampai komplikasi yang mungkin terjadi.

- Sedang : Mengetahui penyakit asma serta gejalanya.

- Tinggi : Tidak mengenal tentang penyakit asma.

- Lama menderita penyakit asma terdiri dari

- $\quad<5$ tahun

- $\quad 5$ - 10 tahun

- $>10$ tahun

3. Kriteria efektifitas ACT diperoleh dengan standar sebagai berikut :

Bila ketepatan pemeriksaan ACT oleh dokter dengan pemeriksaan yang dilakukan secara mandiri oleh pasien mempunyai bias :

$\begin{array}{ll}<5 \% & \text { : sangat efektif } \\ 5-30 \% & : \text { Cukup efektif } \\ >30 \% & : \text { Tidak efektif }\end{array}$


4. Kejadian eksaserbasi: Angka kejadian Serangan akut asma yang memerlukan penanganan dokter di instalasi gawat darurat, selama pasien dalam penelitian.

\section{Alat dan Bahan}

- Kuesioner ACT

- Status pasien penelitian

- Formulir persetujuan ikut penelitian.

- Obat Bronkodilator inhalasi kerja singkat.

- Spirometri

\section{Pengumpulan data dan Analisa Data}

Data yang terkumpul dikelompokkan berdasarkan tujuan dan jenis data kemudian dipilih metode statistik yang sesuai. Hasil yang diperoleh ditampilkan dalam bentuk tabel dan grafik.

\section{Prosedur Penelitian}

1. Semua Pasien Asma yang berobat ke Poliklinik Paru yang memenuhi syarat dan bersedia ikut dalam penelitian dikumpulkan.

2. Dicatat indentitas pasien serta faktor yang ada pada pasien yang akan mempengaruhi penilaian pasien terhadap tingkat kontrolnya.

3. Diterangkan kepada pasien bagaimana cara pengisi kuesioner ACT dan diminta mencatat gejala yang mungkin dirasakannya selama $4 \mathrm{mg}$ pemantauan dan melakukan pengisian secara mandiri setelah 4 minggu kemudian, hal ini dilakukan selama 2 bulan berturut-turut, juga cara untuk mengatasi perburukan gejala yang bisa dilakukan pasien dirumah yang diketahuinya dengan menggunakan ACT.

4. Pasien tetap menggunakan terapi asma yang diberikan oleh dokter di Poliklinik Paru RS. Dr. M. Djamil Padang.

5. Setiap $4 \mathrm{mg}$ Pasien melaporkan berapa nilai ACT yang didapatkannya secara mandiri dan kemudian peneliti juga melakukan penilaian ACT, hasil yang didapatkan peneliti dan pasien dicatat, angka yang didapat oleh peneliti tidak diketahui oleh penderita. Penilaian ACT oleh pasien secara mandiri dilakukan selama 2 kali berturut-turut. Bila dalam pengamatan selama 4 minggu tersebut terjadi perburukan gejala maka yang ditandai dengan penurunan tingkat kontrol asma pasien maka pasien harus segera kontrol ke poli paru untuk mendapatkan penangan yang dibutuhkannya.

\section{HASIL DAN PEMBAHASAN \\ Hasil}

\section{Karakteristik pasien.}

Penelitian ini dilakukan di Poliklinik Paru RS Dr. M. Djamil Padang, mulai dari Juli sampai dengan September 2011. Sebanyak 36 orang penderita asma bersedia ikut dalam penelitian ini, tapi hanya 32 orang yang mengikuti penelitian hingga selesai. Sebagian besar pasien adalah perempuan sebanyak 20 orang $(62,5 \%)$. Usia rata-rata 46,3 tahun, usia tertinggi 75 tahun dan terendah 15 tahun. Nilai rata-rata FEV1 prediksi rata-rata $79 \%$ dan FEV1 /FVC tujuh puluh delapan persen. Karakteristik lengkap dapat dilihat ditabel 1:

Tabel 3. Karakteristik pasien penelitian

\begin{tabular}{lcc}
\hline & \multicolumn{2}{c}{ Subyek $\mathbf{n}(\%)$} \\
\cline { 2 - 3 } Karakteristik Umum & Nilai (n=32) & $\%$ \\
\hline Perempuan & 20 & 62,5 \\
Umur Rata-Rata ( thn) & 46,3 & \\
usia tertinggi (th) & 75 & \\
usia terendah (th) & 15 & \\
Spirometri & & $79 \%$ \\
FEV1 \% pred. & & $78 \%$ \\
FEV1 /FVC \% pred. & & \\
\hline
\end{tabular}

\section{Efektifitas ACT untuk mendeteksi perubahan tingkat kontrol asma}

Efektifitas penggunaan ACT secara mandiri oleh pasien sebagai alat untuk mendeteksi perubahan tingkat kontrol asma, cukup efektif karena penilaian pasien sama dengan dokter yaitu $78,1 \%$, perbedaan yang didapatkan $21,9 \%$ (kecil dari $30 \%$ ).

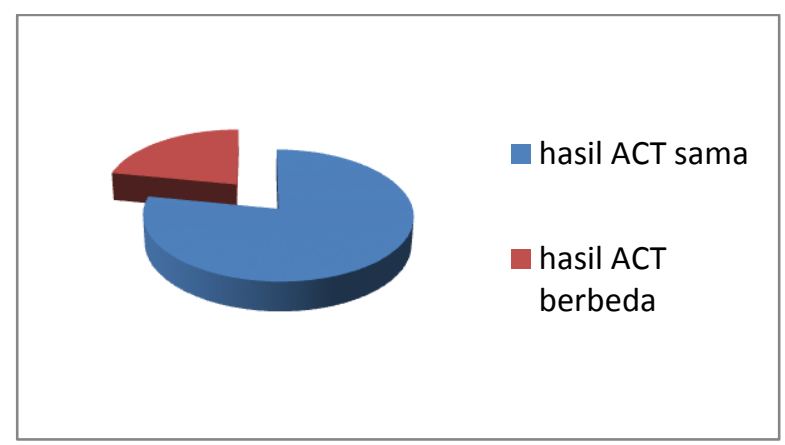

Gambar 2. Efektifitas ACT dalam mendeteksi tingkat kontrol asma secara mandiri oleh pasien 
Perbedaan dalam mendeteksi perubahan tingkat kontrol asma antara dokter dan pasien.

Perbedaan deteksi perubahan tingkat kontrol asma antara dokter dan pasien bulan 1 dan kedua terlihat peningkatan nilai, kemampuan pasien dalam mendeteksi secara mandiri tingkat kontrol asmanya semakin baik hal ini dapat dilihat pada gambar dibawah ini :

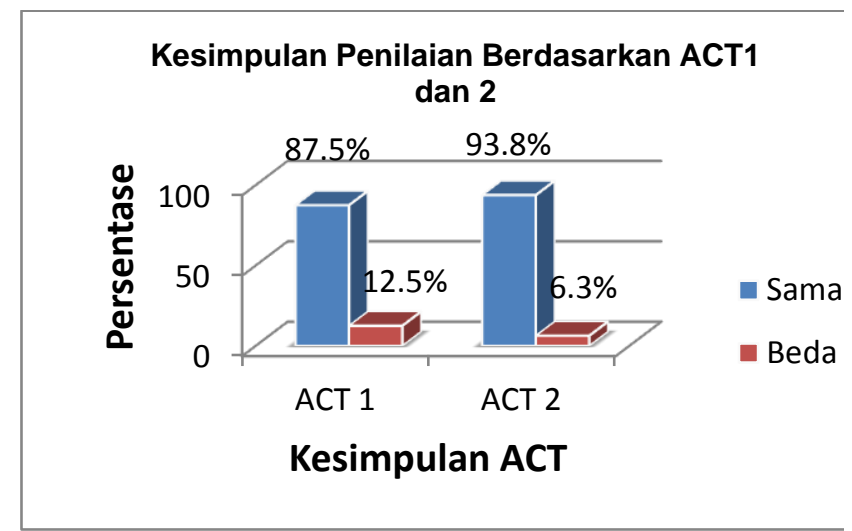

Gambar 3. Perbedaan deteksi perubahan tingkat kontrol asma antara dokter dan pasien.

Faktor yang berhubungan dengan ketepatan Pasien dalam mendeteksi perubahan tingkat kontrol asma dengan ACT secara mandiri.

1. Tingkat pendidikan.

Berdasarkan tingkat pendidikan, pasien dibagi atas berpendidikan tinggi, sedang dan rendah, dilakukan uji statistik untuk melihat hubungan tingkat pendidikan dengan kemampuan mengisi ACT. Didapatkan tidak ada hubungan antara tingkat pendidikan dengan ketepatan pengisian ACT dimana dengan Test Chi-square didapatkan nilai $p=0,636$.

Tabel 4. Pengaruh tingkat pendidikan pasien terhadap hasil penilaian ACT.

\begin{tabular}{llll}
\hline \multirow{2}{*}{ Pendidikan } & \multicolumn{2}{c}{ ACT } & \multirow{2}{*}{ Total } \\
\cline { 2 - 3 } & \multicolumn{2}{c}{ Sama } & \multicolumn{1}{c}{ Beda } \\
\hline Tinggi & $11(44 \%)$ & $4(57,1 \%)$ & $15(46,9 \%)$ \\
Sedang & $12(48 \%)$ & $2(28,6 \%)$ & $14(43,8 \%)$ \\
Rendah & $2(8 \% 0$ & $1(14,3 \%)$ & $3(9,4 \%)$ \\
Total & $25(100 \%)$ & $7(100 \%)$ & $32(100 \%)$ \\
\hline
\end{tabular}

2. Tingkat keparahan asma

Tingkat keparahan asma ternyata tidak berhubungan dengan ketepatan dalam pengisian ACT dimana berat atau ringannya asma sesorang tidak mempengaruhi kemampuan mereka dalam mendeteksi tingkat kontrol mereka. mengisi kuesioner ACT karena didapatkan nilai $p=0,514$. Hal ini dapat dilihat pada tabel 5 .

Tabel 5. Hubungan antara tingkat keparahan asma pasien dan penilaian ACT

\begin{tabular}{llrl}
\hline \multicolumn{1}{c}{ TINGKAT } & \multicolumn{2}{c}{ ACT } & \multirow{2}{*}{ Total } \\
\cline { 1 - 3 } KEPARAHAN & Sama & Beda & \\
\hline Intermiten & $4(16 \%)$ & 0 & $4(12,5 \%)$ \\
Persisten ringan & $9(36 \%)$ & $4(57,1 \%)$ & $13(40,6 \%)$ \\
Persisten sedang & $10(40 \%)$ & $3(42,9 \%)$ & $13(40,6 \%)$ \\
Persisten berat & $2(8 \%)$ & 0 & $2(6,3 \%)$ \\
\hline Total & $25(100 \%)$ & $7(100 \%)$ & $32(100 \%)$ \\
\hline
\end{tabular}

3. Pengetahuan pasien terhadap penyakit asma

Tingkat pengetahuan pasien dibagi atas tinggi, sedang dan rendah berdasarkan pengetahuan mereka terhadap penyakitnya. Dengan melakukan uji chi- square didapatkan nilai $p=0,579$.

Tabel 6. Pengaruh pengetahuan pasien tentang penyakit asma terhadap hasil penilaian ACT

\begin{tabular}{|c|c|c|c|c|}
\hline \multirow{2}{*}{ Pengetahuan } & \multicolumn{3}{|c|}{ ACT } & \multirow{2}{*}{ Total } \\
\hline & Sama & Beda & & \\
\hline Tinggi & $3(12 \%)$ & & 0 & $3(9,4 \%)$ \\
\hline Sedang & $20(80 \%)$ & $6(85,7 \%)$ & & $26(81,3 \%)$ \\
\hline Rendah & $2(8 \%)$ & $1(14,3 \%)$ & & $3(9,4 \%)$ \\
\hline Total & 25 (100\%) & $7(100 \%)$ & & $32(100 \%)$ \\
\hline
\end{tabular}

4. Lama menderita asma

Lamanya pasien menderita penyakit asma tidak memberikan pengaruh dalam ketepatan mereka untuk mengisi kuesioner ACT, hal ini dibuktikan dengan uji statistik bahwa tidak ada hubungan antara lama menderita asma dengan ketepatan pasien dalam mengisi ACT nilai p yang didapatkan adalah 0,119 .

Tabel 7. Hubungan antara lama menderita asma terhadap hasil penilaian ACT

\begin{tabular}{cccc}
\hline \multirow{2}{*}{$\begin{array}{c}\text { Iama menderita } \\
\text { Asma }\end{array}$} & \multicolumn{2}{c}{ ACT } & Total \\
\cline { 2 - 3 }$>10$ tahun & $22(88 \%)$ & $5(71,4 \%)$ & $27(84,4 \%)$ \\
$5-10$ tahun & $1(4 \%)$ & $2(28,6 \%)$ & $3(9,4 \%)$ \\
$<5$ tahun & $2(8 \%)$ & 0 & $2(6,3 \%)$ \\
\hline & $25(100 \%)$ & $7(100 \%)$ & $32(100 \%)$ \\
\hline
\end{tabular}


Angka kejadian eksaserbasi akut pada pasien selama penelitian.

Selama penelitian ini tidak ditemukan adanya eksaserbasi akut pada pasien asma sehingga membutuhkan penanganan di IGD. Hal ini diketahui melalui wawancara yang dilakukan terhadap pasien pada akhir penelitian.

\section{PEMBAHASAN}

\section{Efektifitas ACT untuk mendeteksi perubahan tingkat kontrol asma.}

Efektifitas penggunaan ACT secara mandir oleh pasien untuk mendeteksi secara dini perubahan tingkat kontrol pasien pada penelitian ini adalah efektif dengan angka 78,1\%. Hal ini menggambarkan bahwa ketepatan pasien dengan dokter untuk mengetahui tingkat kontrol asma hampir sama. Penting bagi pasien untuk dapat mengetahui tingkat kontrol mereka agar dapat mendeteksi secara dini perburukan terhadap gejala asma. Karena bila terjadi perburukan, intervensi harus segera dilakukan sehingga tidak terjadi eksaserbasi yang akan meningkatkan angka kesakitan dan kematian pasien asma. Penelitian Lai CK dkk di Hongkong melaporkan penggunaan ACT yang dilakukan secara mandiri oleh pasien dengan yang dilakukan dipelayanan kesehatan mendapatkan hasil yang siganifikan antara keduanya. ${ }^{11}$

\section{Perbedaan dalam mendeteksi perubahan tingkat kontrol asma antara dokter dan pasien.}

Pada penelitian ini terdapat perbedaan penilaian dokter dan pasien $12,5 \%$ pada bulan pertama dan $6,3 \%$ pada bulan kedua. Perbedaan penilaian ini semakin kecil setelah bulan kedua, ini disebabkan pasien semakin mengerti dan mulai memperhatikan gejala-gelala asma yang mereka alami. Dari perbedaan ini terlihat nilai yang didapat pasien lebih tinggi, karena rata-rata dengan pengurangan gejala harian maka pasien sudah merasa sangat baik sehingga penilaian mereka terutama pada pertanyaan no 5 , saat pasien diminta menilai tingkat kontrol mereka sendiri lebih tinggi dibanding dokter. Pada penelitian Shaun Holt dan Kyle Perrin di New Zealand mereka juga mendapatkan perbedaan persepsi pasien terhadap gejala asma mereka dengan dokter, hal ini terutama terjadi pada pasien dengan asma derajat sedang dan berat hal ini disebabkan sebelumnya pasien tidak pernah bebas dari gejala asma, pada saat asma mereka dapat terkontrol dengan baik, sehingga pada saat gejala asma berkurang pasien merasa sangat baik walaupun sebenarnya hal ini masih belum mencapai tingkat asma terkontrol total. ${ }^{12}$ Penelitian Eduardo Vonte dkk mendapatkan hasil yang berbeda, nilai yang didapat oleh pasien lebih rendah bila dibandingkan dokter disebabkan sebagian besar pasien penelitian mereka dengan derajat asma ringan sehingga perbaikan gejala asma tidak begitu mereka rasakan. ${ }^{13}$

\section{Faktor yang berhubungan dengan ketepatan Pasien dalam mendeteksi perubahan tingkat kontrol asma dengan ACT secara mandiri. \\ - Tingkat pendidikan dan pengetahuan terhadap penyakit asma. \\ Pada penelitan ini tidak didapatkan hubungan} antara tingkat pendidikan serta pengetahuan pasien terhadap penyakit asma dengan efektifitas pengisian kuesioner ACT. Kemampuan pasien untuk bisa mendeteksi perubahan tingkat kontrol mereka secara mandiri dengan menggunakan ACT lebih ditentukan oleh penjelasan yang diberikan dokter sebelumnya. Hal ini sama dengan penelitian Rob Horne dan Ponte, dimana yang berpengaruh bukan pendidikan ataupun pengetahuan pasien sebelumnya tentang asma, tapi penjelasan dokter tentang penyakit serta pemahaman gejala asma saat memberikan petunjuk penggunaan ACT. Dengan memberikan penjelasan dan pengertian yang baik, perspektif dokter dan pasien terhadap gejala asma akan sama, sehingga bias yang terjadi bisa dihindari. ${ }^{13,14}$

- Tingkat keparahan asma pasien.

Sebagian besar pasien yang diteliti berada pada tingkat persisten $87,5 \%$, gejala asma sudah sering muncul pada tingkat ini. Kemampuan pasien dalam mendeteksi perubahan tingkat kontrol asma secara mandiri ternyata lebih baik pada tingkat intermiten dan persisten berat dimana semua hasil penilaiannya sama dengan dokter. Walaupun setelah diuji secara statistik tidak mempunyai hubungan. Hal ini bisa disebabkan pada kedua kelompok yang sama dengan dokter, merupakan kelompok dengan tingkat keparahan asma yang ringan, jarang mengalami 
serangan asma sehingga pasien dengan mudah mengingat riwayat serangan asma mereka. Sedangkan pada asma persisten berat mereka berada pada tingkat asma yang tidak terkontrol dimana serangan asma yang timbul hampir sepanjang waktu sehingga nilai yang mereka dapatkan biasnya pada angka 1 atau 2 saja sehingga kesimpulan akhir terhadap kontrol asmanya tetap sama dengan penilaian dokter yaitu kecil dari 19. Hasil yang sama dengan penelitian ini juga dilaporkan oleh Ponte dkk dimana mereka mendapatkan pasien dengan tingkat keparahan asma yang berat, kemampuan mereka dalam mendeteksi tingkat kontrol asma lebih baik karena mereka lebih merasakan perbaikan gejala asmanya dengan pengobatan yang tepat sehingga jelas sekali perubahan yang meraka rasakan. ${ }^{13}$

- Lama menderita asma

Lamanya menderita asma tidak berhubungan dengan kemampuan mendeteksi tingkat kontrol asma pasien secara mandiri. Penelitian ini membuktikan bahwa pasien dengan perbedaan lama menderita asma mempunyai kemampuan yang sama dalam mendeteksi perubahan tingkat kontrol asma mereka. Hal ini disebabkan sebelumnya pasien sudah diberikan penjelasan tentang ACT serta apa yang harus mereka perhatikan dan waspadai agar tidak terjadi perburukan dari tingkat kontrol asma. Pada penelitian di Yunani oleh Grammatopoulou dkk juga tidak ada hubungan yang bermakna antara lama menderita asma dengan hasil ACT yang didapat pasien. $^{15}$

\section{Angka kejadian eksaserbasi akut pada pasien selama penelitian}

Pada penelitian ini tidak ada pasien yang mengalami kejadian eksaserbasi akut sehingga membutuhkan penanganan di instalasi gawat darurat ataupun perawatan dirumah sakit. Pada saat awal penelitian pasien diterangkan bahwa harus segera kembali untuk kontrol ke poliklinik bila ada tanda-tanda perburukan klinis yang dialami pasien, terutama bila mengalami infeksi saluran nafas. Hal ini meyebabkan eksaserbasi pada pasien penelitian bisa ditekan karena bila terjadi perburukan derajat kontrol asma yang mereka temukan dengan menggunakan ACT maka pasien harus segera kembali ke poliklinik untuk mendapat penanganan selanjutnya. Intervensi ini terbukti efektif untuk mencegah eksaserbasi asma. Penelitian Sato dkk mendapatkan kemampuan ACT sebagai prediksi eksaserbasi asma selama 1 tahun adalah $60,3 \%$. Perbedaan nilai ini disebabkan Sato hanya menggunakan ACT untuk memprediksi eksaserbasi pada pasien asma yang tidak terkontrol sedang pada penelitian ini ACT digunakan untuk semua tingkat kontrol asma. ${ }^{16}$

\section{KESIMPULAN DAN SARAN}

\section{Kesimpulan}

1. Penggunaan ACT cukup efektif dalam mendeteksi perubahan tingkat kontrol asma pasien secara mandiri.

2. Perbedaan kemampuan dokter dengan pasien dalam mendeteksi perubahan tingkat kontrol asma kecil, $12,5 \%$ pada bulan pertama dan $6,3 \%$ pada bulan kedua.

3. Efektifitas penggunaan ACT sebagai alat untuk mendeteksi perubahan tingkat kontrol asma tidak punya hubungan dengan pendidikan pasien, tingkat keparahan asma, tingkat pengetahuan awal pasien terhadap penyakit asma serta lama menderita asma.

4. Selama penelitian dengan menggunakan ACT sebagai follow-up tidak ditemukan kejadian eksaserbasi asma.

\section{SARAN}

1. Penggunaan ACT secara mandiri oleh pasien sangat dianjurkan karena dapat mendeteksi perubahan tingkat kontrol asma sehingga penyesuaian terapi untuk menghindari eksaserbasi akut.

2. Asthma control test dapat dipakai untuk semua pasien asma karena tidak dipengaruhi oleh pendidikan pasien, tingkat keparahan asma, tingkat pengetahuan awal pasien terhadap penyakit asma serta lama menderitanya asma

\section{DAFTAR PUSTAKA}

1. PDPI, Asma, Pedoman diagnosis dan penatalaksanaan di Indonesia. Jakarta. Balai penerbit FKUI, 2004. 
2. GINA, 2009. National Heart, Lung, and Blood Institute (NH`LI). Global Initiative for Asthma. 2009.

3. RABE AG et.al., 2000. Clinical management of Asthma in 1999 : The asthma insights and reality in Europe (AIRE) study. Eur Respir J.16:802-7.

4. Bateman ED, Can Guideline-defined Asthma Control be achieved?. Am J Respir Crit Care med.2004;170: 836-44.

5. Badan Penelitian dan Pengembangan Kesehatan Departemen Kesehatan RI, 2007. Riset Kesehatan Dasar (RIKESDA). Laporan Nasional 2008. 94-8.

6. GINA, National Heart, Lung, and Blood Institute (NHLBI). Global Initiative for Asthma. 2006.

7. Pedersen S, From asthma severity to control: a shift in clinical practice. Primary Care Respiratory Journal. 2010. 19(1): 3-9.

8. Lang DM, New Asthma guidelines emphasize control, regular monitoring. Cleveland clin.J.med. 2008. vol.75: 641-53.

9. Fuhlbrigge $A L$, The Burden of Asthma in the United States. Am J respir crit Care Med. 2002.;166:1044-9.

10. Li JT, 2005. Attaining Optimal Asthma Control: a Practice Parameter. J Allergy Clin
Immunol.112; 2008.

11. Lai CK, Ko FW, Bhome A, DE Guia TS, Wong GE et.alRelationship between Asthma Control status, the ACT and urgent healthcare utilization in Asia. Respirology. . 2011. Vol.16(4). pp 688-97.

12. Holt S, Perrin K. Using the asthma control test to improve asthma outcomes. Journal of the New Zealand medical Association. 2010. Vol 123 no.1323.

13. Ponte EV, Petroni J, Ramos DCB, Pimental L, Freitas D et.al. Perception of asthma control in asthma patients. J Bras Pneumol. 2005. 33(6); 635-40.

14. Horne R, Price D, Cleland J, Costa R, Covey D, et.al. Can asthma be improved by understanding the patient's perspective? 2007. BMC Pulmonary Medicine 2007, 7:8.

15. Grammatopoulou EP, Stavrou N, Myriantiefs P, Karteroliotis K, Baltopoulos G. Validity and reability evidence of ACT in Greece. Journal of asthma, 2010. 1-8.

16. Soto $R$, Tomita $K$, Sano $H$, Ichihashi $H$, Yamagata $S$, et.al. The Strategy for Predicting Future Exacerbation of Asthma Using a Combination of the Asthma Control Test and Lung Function Test. Journal of asthma, 2009. 46:677-82. 